\title{
SOCIAL ECONOMY AND POSYANDU SERVICES IN DESA KALIANYAR, BONDOWOSO DISTRICT AS VILLAGE WITHOUT STUNTING
}

\author{
Yuana Dwi Agustin'1), Andrielina Firdausih2) \\ 1School of Nursing Diploma, Universitas Bondowoso \\ ${ }^{2} \mathrm{School}$ of Guidance and Counseling, Universitas Bondowoso
}

\begin{abstract}
BACKGROUND : Stunting has the highest prevalence compared to malnutrition, lack of nutrition, and fat. Stunting is identified characteristic of a child's length or height. Stunting is a nutritional problem that affects human resources. Stunting can happen dur to many factors as posyandu services and socio economic. This study is conduct to determine the socioeconomic characteristics and posyandu services in Kalianyar village where there are no cases of stunting.

SUBJECT AND METHODE : This reseach used GIAN questionnaire through the East Java Provincial Health Office to collection the data. The subject were 15 mothers from Kalianyar Village selected by data of posyandu. The result of thid study showed that the important things to prevent stunting were water sources, mother's education, visits to the posyandu and the need to pay attention to posyandu services.
\end{abstract}

RESULTS : (93.3\%) had taken their children to go to Posyandu and there were $6.7 \%$ of subjects who had never taken their children to go to Posyandu, $73,3 \%$ subject familiar with emo-demo and $26,7 \%$ never knew about emo-demo. Almost (66,7\%) subjectattend in emo-demo activity and 33,3\% never attend in emo demo.

CONCLUSION : Some things that can be considered to prevent stunting, are water sources, mother's education, visits to the posyandu and the need to pay attention to posyandu services

Keyword : Stunting, Socio economy, posyandu services

\section{INTRODUCTION}

Indonesia is having a serious nutritional problem, namely stunting. Stunting is a nutritional problem that affects human resources (HR) (Kementrian Desa, Pembangunan Daerah Tertinggal, dan Transmigrasi, 2017). Based on Nutrition Status Monitoring (PSG) data, stunting has the highest prevalence compared to malnutrition, lack of nutrition, and fat (Buletin Jendela Data dan Infromasi Kesehatan, 2018).

The prevalence of stunting is increasing at 2017. The increase in short toddlers occurred from $2016(27.5 \%)$ and $29.6 \%$ in 2017 . The prevalence of toddlers is very short and short age $0-59$ months in 2017 is $9.8 \%$ and $19.8 \%$. This condition has increased from $8.5 \%$ and $19 \%$ the previous year (Buletin Jendela Data dan Infromasi Kesehatan, 2018).

The government has set policies related to stunting. Prevention of stunting includes the 20152019 RPJMN. The prevention policy faces five obstacles including, 1) ineffective stunting prevention program, 2) ineffective coordination of specific and sensitive intervention providers, 3) ineffective and efficient allocation and utilization of resources and 4) limited capacity and quality of program 
providers, 5) lack of advocacy, campaigning, and dissemination related to stunting and other stunting prevention efforts (Tim Nasional Percepatan Penanggulangan Kemiskinan, 2018).

Prevention of stunting can be through everal ways, namely prevention by fulfilling the nutrition of pregnant women, exclusive breastfeeding until the age of 6 months and providing complementary feeding (MPASI) after 6 months of sufficient quality, bringing toddlers to control growth in Posyandu, and increasing water access clean and sanitary facilities, and protect the surrounding environment(Sutarto, Mayasari, dan Indriyani, 2018).

The results of the stunting consultation with Bondowoso government on 9 July 2019, showed that Bondowoso was ranked the third highest in East Java related to stunting rates(Kabar Jatim, 2019). Posyandu in Bondowoso Regency showed that there are several villages where there are no stunted toddlers and stunts. One of them is Kalianyar village.

Therefore, the researchers conducted a study in Kalianyar Village to determine the socioeconomic characteristics and posyandu services in Kalianyar village where there were no cases of stunting. So the results of research related to village conditions can be a picture for other villages.

\section{METHODE}

The variables examined in this study were social economy and posyandu services. Socioeconomics is a variable that describes social and economics, namely the last education, type of work, home ownership, type of building materials and house walls, type of lighting, waterways, sanitation, to fuel oil used.

Posyandu service variables consist of the existence of KMS, KIA, frequency of inviting children to come to posyandu, type of posyandu services provided, provision of vitamin $A$ and intestinal worms, frequency of implementing emodemo to the topic of emodemo.

This study involving 15 mothers in the village ofyaryar have children under five years old and under two years old. Subject data were obtained from surrounding Posyandu. Data collection was used a GAIN questionnaire through the East Java Provincial Health Office. Data processing was coding that used Excel and descriptive analysis by SPSS Program.

\section{RESULT AND DISCUSSION}

The results showed that the average mother had a junior and senior high school education. Ni'mah and Nadhiroh's research (2015) shows that maternal education is related to stunting cases, in which more than half of stunting cases occur in mothers with low education. The level of education will affect the nutritional status, because someone who is highly educated will know more about healthy lifestyles and how to maintain health (Hidayat and Ismawati,).

Table 1. Data on educational characteristics

\begin{tabular}{ccc}
\hline Education & $\mathrm{N}$ & Precentage (\%) \\
\hline (person) & 6,7 \\
Bachelor degree & 1 & 33,3 \\
Junir High School & 5 & 33,3 \\
Elementary School & 5 & 13,3 \\
Uneducated & 2 & 13,3 \\
\hline Total & 2 & 100 \\
\hline
\end{tabular}


The results of figure 1 showed that there were $20 \%$ of working mothers. The status of working mothers is not related to the nutritional status of children, because children can still be fulfilled their nutritional intake even with caregivers (Wulanta, Amisi, Punuh, 2018).

In Figure 2, more subjects (66.7\%) had a toilet and $20 \%$ did not have a toilet, so they defecated in ponds or rivers.

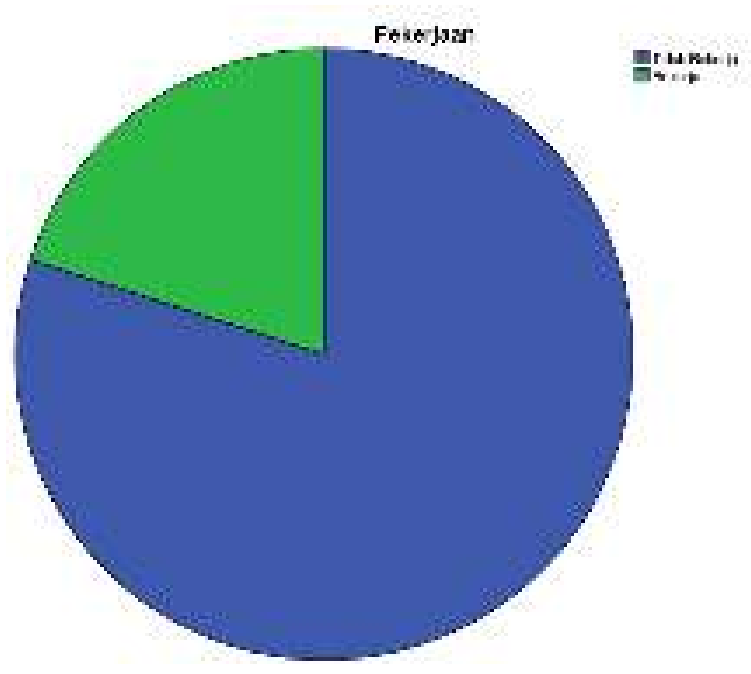

(1)

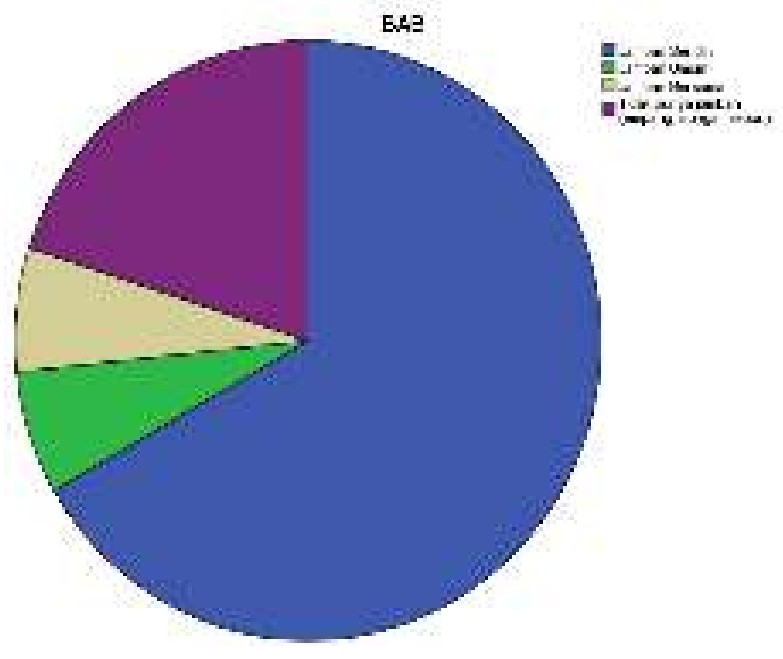

(2)

Figure 1 and 2. Frequency Distribution of Respondent based on Occupation and Latrin Ownership

Table 2 Characteristics of home ownership, lighting, and water sources data

\begin{tabular}{lcc}
\multicolumn{1}{c}{ Characteristict } & N & Percentage (\%) \\
\hline House Ownership & (Person) & \\
Own house & 7 & 46,7 \\
Parents house & 8 & 53,3 \\
$\quad$ Total & 15 & 100 \\
\hline Source of Water & & \\
$\quad$ Protected dug well & 13 & 86,7 \\
$\quad$ Unprotected dug well & 2 & 13,3 \\
Total & 15 & 100 \\
\hline
\end{tabular}

More than half of the subjects lived in the homes of parents $(53,3 \%)$ and $46,7 \%$ lived in own homes. The whole subject used PLN (Perusahaan Linstrik Negara) lighting. Water sources were obtained from protecct dug wells in $86,7 \%$ of subject and water sources by unprotected dug wells as much $13,3 \%$.

The results showed that $86.7 \%$ of subjects obtained water from protected dug wells and $13.3 \%$ obtained water from unprotected dug wells $13.3 \%$. Poor sanitation effected of infectious diseases such as diarrhea and intestinal worms. Infectious diseases made weight loss and made stunting if they occur for a long time and are not balanced with adequate intake. Proper drinking water sources are protected drinking water namely tap water public hydrants, water terminals, 
penampungan air hujan(PAH), boreholes or pumps a distance of 10 meters from the landfill of sewage, waste, and garbage (Buletin Jendela Data dan Informasi Kesehatan, 2017).

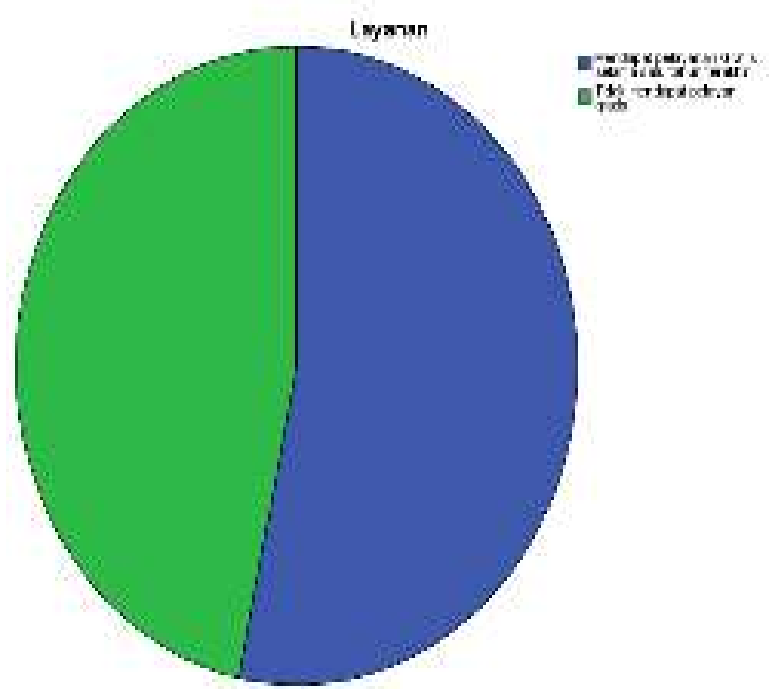

Figure 3 Data of obtained services

Figure 3 showed that more subjects have received free services (53.3\%) compared to subjects who did not get free services (46.7\%).

Table 3 Data on subjects obtaned RASKIN (Beras Miskin)

\begin{tabular}{lccc}
\hline \multicolumn{1}{c}{ Characteristict } & N & Percentage $(\%)$ \\
\hline Get RASKIN & & 12 & 80 \\
Not getting RASKIN & 3 & 20 \\
\hline \multicolumn{2}{c}{ Total } & 15 & 100
\end{tabular}

Table 3 showed that more subjects received RASKIN (80\%) compared to those who did not get RASKIN (20\%).

The results also showed that the whole subject had a book-shaped KMS

Figure 4 showed that almost all subjects had a Kartu Ibu dan Anak (KIA), namely $86.7 \%$ of the subjects and there were $13.3 \%$ of the subject's children who did not have a KIA. 

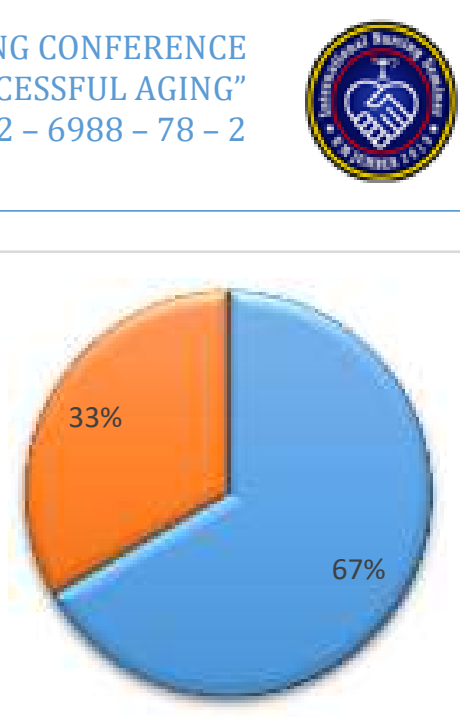

- Pernah menghadiri emo-demo

- Tidak pernah menghadiri emo-demo

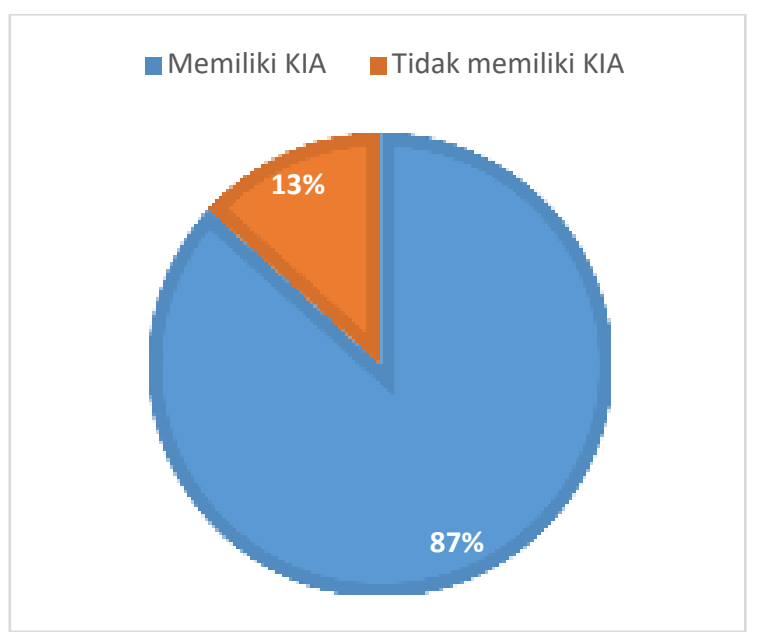

Figure 4 and 5. The ownership of KIA and Posyandu Visit in Kaliantar Village

Figure 5 showed that almost all subjects (93.3\%) had taken their children to go to Posyandu and there were $6.7 \%$ of subjects who had never taken their children to go to Posyandu.

Types of posyandu services provided according to the subject, including weight weighing, height measurement, supplementary food (PMT), immunization, health checks, breastfeeding 
counseling, supplementary feeding counseling, breastfeeding counseling, supplementary feeding counseling, administration, giving zinc when diarrhea, other drugs.

The results showed that almost subjects had taken children to the posyandu. Posyandu is a place that intervenes in cases of stunting because mothers can monitor the growth of children (Ministry of villages, development of disadvantaged areas, and transmigration, 2017). The results of Destiadi, Nindyia, and Sumarmi's research obtained the results of the study that children who were less active in coming to the Posyandu were at 3.1 times the risk of being stunted compared to children who were actively coming to the posyandu. This is because the posyandu is a place to monitor the nutritional status and growth of the right child because the child will be measured first in weight and height every month (Destiadi, Nindyia, and Sumarmi, 2015).

Tabel 4 Data of getting Vit A, cacingan drug, and taburia

\begin{tabular}{lcc}
\multicolumn{1}{c}{ Characteristict } & N & Percentage (\%) \\
\hline Getting Vit A & 14 & \\
Getting Vit A & 1 & 93,3 \\
Never getting Vit A & 15 & 6,7 \\
Total & & 100 \\
Getting cacingan drug & 14 & \\
$\quad$ Getting cacingan drug & 1 & 93,3 \\
$\quad$ Never getting cancingan drug & 15 & 6,7 \\
\hline Total & & 100 \\
\hline
\end{tabular}

Tabel 4 showed that almost subjects getting vit A and cacingan drug (93,3\%). All subjects never getting or never consumption of taburia (multivitamin that spread on child food).

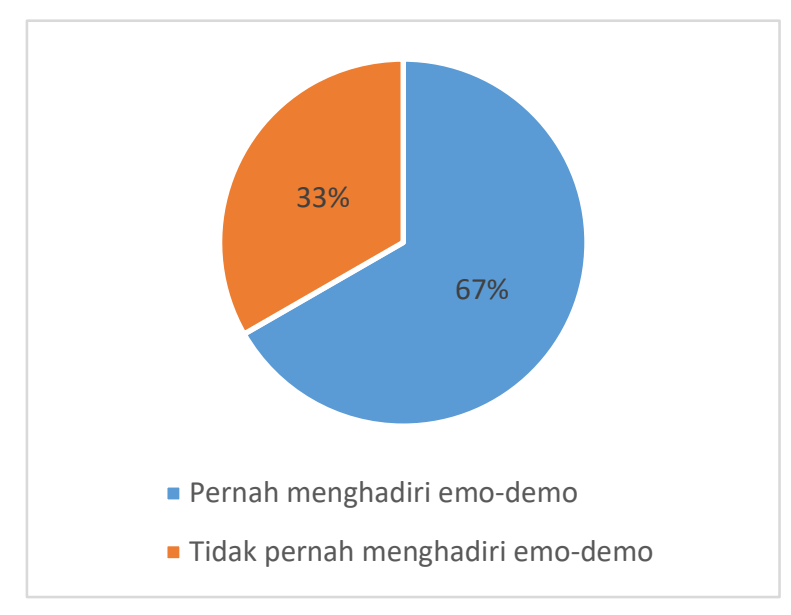

Figure 5 Data of presence in emo-demo activity

Figure 5 showed that $73,3 \%$ subject familiar with emo-demo and $26,7 \%$ never knew about emo-demo. Almost (66,7\%) subjectattend in emo-demo activity and 33,3\% never attend in emo demo. The topic of emo demo were 1) Giving ASI (Air Susu lbu), 2) Attachement between mother and child, then 3 )Siap berpergian. 
The existence of posyandu has many benefits, including being able to carry out cadre education to provide knowledge related to the importance of nutrition the first 100 days of birth, monitoring nutritional status related to stunting. Posyandu can be carried out with the role of the posyandu cadres, including preparing the place and equipment for posyandu activities, recording KMS results or, weighing infants and pregnant women, providing health and family planning services, such as providing vitamin A, iron tablets, ORS, family planning devices, and others. Posyandu cadres work closely with health workers on duty in the village. So the existence of posyandu is very important to overcome nutritional problems (Purwanti, 2019).

\section{CONCLUSIONS AND SUGGESTIONS}

Some things that can be considered to prevent stunting, are water sources, mother's education, visits to the posyandu and the need to pay attention to posyandu services.

Pregnant women, mothers with toddlers and young people need to be diligent in coming to the posyandu to obtain health-related services and can participate in other activities such as emodemos that can increase knowledge to prevent stunting.

For health workers to remain defensive in providing services for pregnant women under five, baduta, paud as a form of support in preventing stunting. It is also necessary to provide awareness for pregnant women, mothers with toddlers and baduta to regularly come to the posyandu.

\section{REFERENCES}

Destiadi, Nindya, Sumarni. 2015. Frekuensi kunjungi posyandu dan riwayat kenaikan berat badan sebagai faktor resiko kejadian stunting pada anak usia 3-5 tahun. Media Gizi Indonesia. 1(1), 71-75.

Hidayat \& Ismawati. 2019. Faktor-faktor kejadian stunting pada balita di wilayah kerja UPT Puskesmas Kramatwatu Kabupaten Serang. Jurnal Bimtas. 3(1).

Kementrian Desa, Pembangunan Daerah Tertinggal, dan Transmigrasi. 2017. Buku Saku Desa dalam Penangan Stunting. Jakarta : Kementrian Desa, Pembangunan Daerah Tertinggal,dan Transmigrasi.

Ni'mah K \& Nadhiroh SR. 2015. Faktor yang berhubungan dengan kejadian stunting pada balita. Media Gizi Indonesia. 10(1), 13-19.

Tim Redaksi. 2018. Buletin Jendela Data dan Informasi Kesehatan. Jakarta : Pusat Data dan Informasi Kementrian Kehesehatan RI.

Priyanto, E. (9 Juli 2019). Angka stunting masih tinggi, Bondowoso peringkat ketiga di Jawa Timur. Kabar Jatim. Retrieved from https://kabarjatim.com/angka-stunting-masih-tinggi-bondowosoperingkat-ketiga-di-jawa-timur/

Purwanti, R. (2019). Program Gastizi 1000 dalam meningkatkan kapasitas kader Posyandu. AcTion: Aceh Nutrition Journal, 4(1), 15. https://doi.org/10.30867/action.v4i1.144

Sutarto, Mayasari, dan Indriyani. 2018. Stunting, faktor resiko, dan pencegahannya. J Agromedicine. $5(1): 540-545$ 
Tim Nasional Percepatan Penanggulangan Kemiskinan (TNP2K). 2018. Strategi nasional percepatan pencegahan stunting 2018-2024. Jakarta : TNP2K.

Wulanta E, Amisi MD, Punuh Ml. 2019. Hubungan antara status sosial ekonomi dengan status gizi pada anak usia 24-59 bulan di Desa Kima Bajo Kecematan Wori Kabupaten Minahasa Utara. Jurnal KESMAS. 8 (5). 